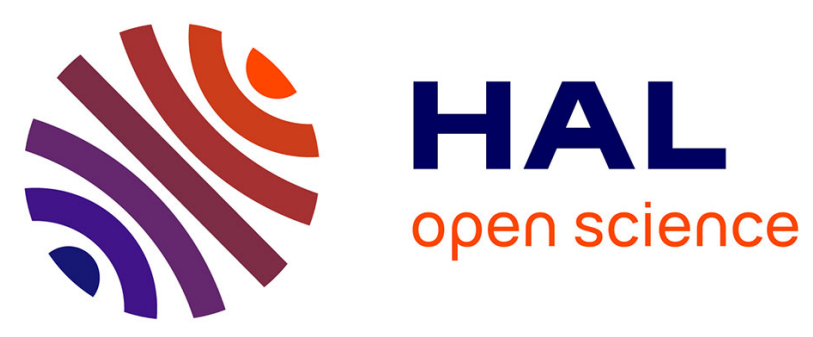

\title{
Reconstitution of the myeloid and lymphoid compartments after the transplantation of autologous and genetically modified CD34+ bone marrow cells, following gamma irradiation in cynomolgus macaques.
}

Sonia Derdouch, Wilfried Gay, Didier Négre, Stéphane Prost, Mikael Le Dantec, Benoit Delache, Gwenaëlle Auregan, Thibault Andrieu, Jean Jacques J. J. Leplat, Cosset François-Loïc, et al.

\section{- To cite this version:}

Sonia Derdouch, Wilfried Gay, Didier Négre, Stéphane Prost, Mikael Le Dantec, et al.. Reconstitution of the myeloid and lymphoid compartments after the transplantation of autologous and genetically modified CD34+ bone marrow cells, following gamma irradiation in cynomolgus macaques.. Retrovirology, 2008, 5, pp.1-15. 10.1186/1742-4690-5-50 . hal-02665763

\section{HAL Id: hal-02665763 \\ https://hal.inrae.fr/hal-02665763}

Submitted on 31 May 2020

HAL is a multi-disciplinary open access archive for the deposit and dissemination of scientific research documents, whether they are published or not. The documents may come from teaching and research institutions in France or abroad, or from public or private research centers.
L'archive ouverte pluridisciplinaire HAL, est destinée au dépôt et à la diffusion de documents scientifiques de niveau recherche, publiés ou non, émanant des établissements d'enseignement et de recherche français ou étrangers, des laboratoires publics ou privés. 


\title{
Reconstitution of the myeloid and lymphoid compartments after
} the transplantation of autologous and genetically modified CD34+ bone marrow cells, following gamma irradiation in cynomolgus macaques

\author{
Sonia Derdouch ${ }^{1,2}$, Wilfried Gay ${ }^{1,2}$, Didier Nègre ${ }^{3,4,5}$, Stéphane Prost ${ }^{1,2}$, \\ Mikael Le Dantec 1,2, Benoît Delache ${ }^{1,2}$, Gwenaelle Auregan1,2, \\ Thibault Andrieu ${ }^{1,2}$, Jean-Jacques Leplat ${ }^{6,7}$, François-Loïc Cosset ${ }^{3,4,5}$ and \\ Roger Le Grand*1,2
}

Address: ${ }^{1}$ CEA, service d'Immuno-Virologie, Institut des Maladies Emergentes et Thérapies Innovantes, Direction des Sciences du Vivant, Fontenay aux Roses, France, ${ }^{2}$ Université Paris-Sud, UMR-E01, Orsay, France, ${ }^{3}$ Université de Lyon, (UCB-Lyon1), IFR128, Lyon, F-69007, France, ${ }^{4}$ INSERM, U758, Lyon, F-69007, France, ${ }^{5}$ Ecole Normale Supérieure de Lyon, Lyon, F-69007, France, ${ }^{6} \mathrm{CEA}$, DSV, IRCM, SREIT, Laboratoire de Radiobiologie et d'Etude du Génome, Jouy-en-Josas, F-78352 France and 7INRA, DGA, Laboratoire de Radiobiologie et d'Etude du Génome, Jouy-en-Josas, F78352 France

Email: Sonia Derdouch - sonia.derdouch@necker.fr; Wilfried Gay - wgaylen@orange.fr; Didier Nègre - didier.negre@ens-lypn.fr; Stéphane Prost - stephane.prost@cea.fr; Mikael Le Dantec - mikael.ledantec@9online.fr; Benoît Delache - benoit.delache@cea.fr; Gwenaelle Auregan - gwenaelle.auregan@cea.fr; Thibault Andrieu - thibault.andrieu@cea.fr; Jean-Jacques Leplat - jean-jacques.leplat@cea.fr; François-Loïc Cosset - flcosset@ens-lyon.fr; Roger Le Grand* - roger.le-grand@cea.fr

* Corresponding author

Published: 19 June 2008

Retrovirology 2008, 5:50 doi:10.1186/1742-4690-5-50

This article is available from: http://www.retrovirology.com/content/5/I/50

This is an Open Access article distributed under the terms of the Creative Commons Attribution License (http://creativecommons.org/licenses/by/2.0), which permits unrestricted use, distribution, and reproduction in any medium, provided the original work is properly cited.

\begin{abstract}
Background: Prolonged, altered hematopoietic reconstitution is commonly observed in patients undergoing myeloablative conditioning and bone marrow and/or mobilized peripheral blood-derived stem cell transplantation. We studied the reconstitution of myeloid and lymphoid compartments after the transplantation of autologous $\mathrm{CD} 34^{+}$bone marrow cells following gamma irradiation in cynomolgus macaques.

Results: The bone marrow cells were first transduced ex vivo with a lentiviral vector encoding eGFP, with a mean efficiency of $72 \% \pm 4 \%$. The vector used was derived from the simian immunodeficiency lentivirus SIVmac25I, VSV-g pseudotyped and encoded eGFP under the control of the phosphoglycerate kinase promoter. After myeloid differentiation, GFP was detected in colony-forming cells $(37 \% \pm 10 \%)$. A previous study showed that transduction rates did not differ significantly between colony-forming cells and immature cells capable of initiating long-term cultures, indicating that progenitor cells and highly immature hematopoietic cells were transduced with similar efficiency. Blood cells producingeGFP were detected as early as three days after transplantation, and eGFP-producing granulocyte and mononuclear cells persisted for more than one year in the periphery.
\end{abstract}

Conclusion: The transplantation of $\mathrm{CD}_{3} 4^{+}$bone marrow cells had beneficial effects for the ex vivo proliferation and differentiation of hematopoietic progenitors, favoring reconstitution of the T- and Blymphocyte, thrombocyte and red blood cell compartments. 


\section{Background}

Gene therapy strategies hold promise for the treatment of hematopoietic disorders. All hematopoietic lineages, including polymorphonuclear cells, monocytes, lymphocytes and natural killer cells, and hematopoietic stem cells (HSC) - which are capable of self-renewal and pluripotent differentiation - have been targeted for transduction with therapeutic genes. Most diseases for which gene therapy could be proposed require stable and longlasting transgene expression for efficacy. Retroviral vectors present the major advantage of integrating the transferred DNA stably into the genome of target cells, which is then passed on to progeny. However, they cannot infect and integrate into non dividing cells[1]. Most HSC are quiescent [2], respond slowly to stimulation [3-7] and tend to differentiate and lose their repopulating capacity upon stimulation[3,8-11]. Lentiviral vectors can be used to transduce cells in growth arrest [12] in vivo and ex vivo[13], thanks to interaction of the preintegration complex composed of viral VPX and integrase proteins - with the nuclear pore complex[14]. Vectors derived from HIV$1[15,16]$, HIV-2[17], FIV[18] and equine infectious anemia virus (EIAV)have been tested[19].

Methods for transferring genes into hematopoietic cells must be tested in relevant animal models before their application to humans $[20,21]$. Studies in nonhuman primates (NH)P provide an ideal compromise, because these species are phylogenetically closely related to humans and a high level of nucleotide sequence identity is observed between the genes encoding many hematopoietic growth factors and cytokines in these mammals and their counterparts in humans[22]. Moreover, hematopoiesis in macaques is very similar to that in humans, and the HSC biology of macaques is much more similar to that of humans than is that of rodents, making macaques good candidates for hematopoietic stem cell engraftment studies [23-26]. In addition, testing lentiviral based gene transfer strategies need to be assessed in species that are susceptible to lentivirus induced disease. Or particular interest are the Feline immunodeficiency virus (FIV) infection which causes a clinical disease in cats that is remarkably similar to HIV disease in human [27-30] and experimental infection of macaques with the simian immunodeficiency virus (SIV) reproducing both chronic infection and an AIDS-like disease very similar to those observed in human patients infected with HIV. Despite the theoretical advantages of lentiviral vectors over oncoretroviral vectors, non human primate lentiviruses clearly have pathogenic properties [31]. The use of lentiviral vectors derived from potentially pathogenic primate lentiviruses, such as SIV, therefore continues to raise serious clinical acceptance concerns. SIV-based vectors, such as SIVmac239[31,32] and SIVmac251[33,34], may pro- vide a unique opportunity to test the safety and efficacy of primate lentiviral vectors in vivo.

Recent improvements in the efficiency of gene transfer to NHP repopulating cells $[11,35,36]$ have provided new opportunities to follow the progeny of each primitive progenitor and stem cells directly in vivo, using retroviral marking to track individual progenitor or stem cell clones[37]. Clinically relevant levels (around 10\%) of genetically modified cells in the peripheral blood have been achieved by ex vivo gene transfer into HSC and the autologous transplantation of these cells into macaques[37]. Successful and persistent engraftment (up to six months) has also been reported in non human primates with primitive CD34+ progenitors genetically modified with a murine retrovirus vector encoding the murine CD24 gene as a reporter gene[38]. In both trials, marked cells of multiple hematopoietic lineages were identified in the blood: granulocytes, monocytes and $\mathrm{B}$ and $\mathrm{T}$ cells, including naive $\mathrm{T}$ lymphocytes[37,38]. The efficacy of HSC gene transfer could theoretically be improved by the use of newly developed retroviral or lentiviral vectors. Particles bearing an alternative envelope protein, such as that of the feline endogenous virus (RD114), have been shown to be superior to amphotropic vectors for the transduction of NHP stem cells followed by autologous transplantation $[39,40]$.

We report here the results obtained in vitro and in vivo in an experiment assessing the efficacy and safety of a gene transfer protocol based on the transduction of simian CD34+ bone marrow cells with a minimal SIVmac251derived lentiviral vector. This system is based on the VSVgpseudotyped SIV vector encoding enhanced green fluorescent protein (eGFP) under control of the phosphoglycerate kinase (PGK) promoter. Most immature CD34+ hematopoietic cells capable of initiating long-term culture (LTC-IC) were efficiently transduced, and eGFP-positive cells were detectable in vivo in all animals more than one year after transplantation.

\section{Methods \\ Animals}

Male cynomolgus macaques (Macaca fascicularis), weighing between 3 and $6 \mathrm{~kg}$ were imported from Mauritius and housed in single cages within level 3 biosafety facilities, according to national institutional guidelines (Commission de génie génétique, Paris, France). All experimental procedures were carried out in accordance with European guidelines for primate experiments (Journal Officiel des Communautés Européennes, L358, December 18 1986). 


\section{Immunoselection of non human primate CD34+ bone marrow progenitor cells}

Bone marrow mononuclear cells were obtained from the iliac crest or by aspiration from the humerus and isolated by standard Ficoll density-gradient centrifugation (MSL2000, Eurobio, Les Ulis, France). Cells were washed twice in phosphate-buffered saline (PBS, Eurobio, Les Ulis, France) and resuspended in 1\% FCS (Fetal Calf Serum; Bio West, France) in PBS. The cellular fraction was then enriched in CD34+ cells by positive immunomagnetic selection, using beads coupled to a specific antibody (clone 561; Dynabeads M-450 CD34, Progenitor Cell Selection System, Dynal, Oslo, Norway), according to the manufacturer' s instructions. Immunoselected CD34+ cells were stained with a specific PE-conjugated anti-CD34 antibody (clone 563; Pharmingen, Becton Dickinson, California, USA) and analyzed by flow cytometry (LSR, Becton Dickinson, California, USA) to evaluate the level of enrichment. All preparations contained more than $95 \%$ CD $34^{+}$cells, with a mean value of $97 \% \pm 1 \%(n=12)$ for in vitro assays and $96 \% \pm 1 \%(\mathrm{n}=4)$ for in vivo assay.

\section{Lentiviral vector}

Two SIV-derived vectors were produced, one for in vitro studies and the other for in vivo studies: 1) pRMES8 is a minimal packaging-competent SIVmac251-based vector[34]. It contains the enhanced green fluorescent protein (eGFP) marker gene under control of the mouse phosphoglycerate kinase (PGK) promoter, placed between the SIVmac251 LTRs and leader sequences. It carries the SIVmac251 RRE region and minimal sequences of the gag and pol genes encompassing central polypurine tract/central termination sequence (cPPT/CTS) regions (figure 1A). pRMES8 was used for in vitro assays investigating the susceptibility of $\mathrm{CD} 34^{+}$cells from primate bone marrow to transduction with SIVmac251-derived vectors. 2) For in vivo assays, we used pGASE; this plasmid is an optimised version of pRMES8, with a 3'-SIN-LTR for safety and insertion of an exon splicing enhancer (ESE) upstream the PGK promoter to increase titer [41]

$\mathrm{pSIV}^{+}$is the packaging plasmid derived from the BK28 molecular clone of SIVmac251, as described elsewhere[33]. Briefly, the pSIV3+ gag/pol expression plasmid
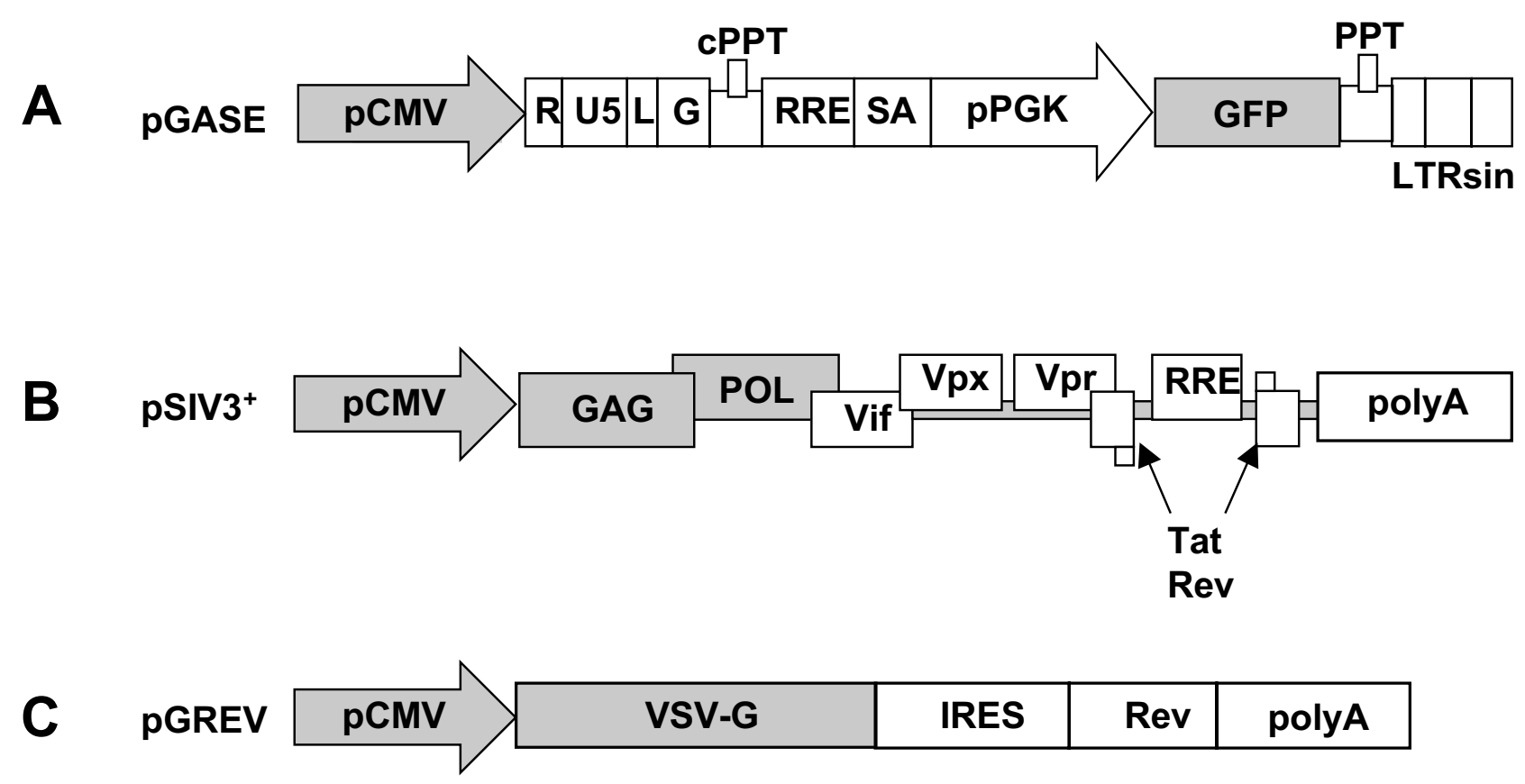

Figure I

Schematic representation of SIV-derived SIN vector, helper construct and VSV-g encoding plasmid. An SIVmac25I-derived vector was produced by cotransfecting 293T cells with three plasmids: A. a plasmid pGASE containing the eGFP gene under control of the PGK promoter; B. a plasmid pSIV3+ containing viral genes; C. a plasmid pGREV containing the VSV envelope gene. Cis genetic elements are symbolized with white boxes, whereas promoters and genes are depicted by shadowed boxes. $\mathrm{PCMV}$, early cytomegalovirus promoter; PPGK, mouse phosphoglycerate kinase-I promoter; RRE, REV-responsible element; SA, SIV Rev/Tat splice acceptor; cPPT and PPT, central and 3' polypurine tracks, respectively; GFP, the gene encoding the enhanced green fluorescent protein; LTRsin, partially U3 deleted 3'LTR; LG, leader and a 5' GAG region. 
was obtained by replacing the 5' LTR of SIVmac251 (nucletotides 1 to 506) by the human cytomegalovirus (CMV) early-immediate promoter and enhancer region. The 5' half of the env gene (nt 6582 to 7981) was also removed, leaving the RRE (REV-responsive element) sequence and the 5' and 3' exons of the tat and rev regulatory genes intact. The 3' LTR (nt 9444 to 10249) was replaced by a SV40 polyadenylation sequence, resulting in deletion of the 3' end of the nef gene. Finally, the nef initiation codon was inactivated to prevent translation (figure 1B).

pGREV was used for pseudotyping. It is a bicistronic expression construct encoding the vesicular stomatitis virus glycoprotein (VSV-g) and the REV regulatory protein, linked by an EMCV IRES. Expression of this cassette, which contains the rabbit $\beta$-globin intron II and polyadenylation ( $\mathrm{pA}$ ) sequences (figure 1C), is driven by the constitutive CMV promoter.

\section{Production of SIV vectors}

293 T cells were plated at a density of $4.0 \times 10^{5}$ cells per well (in 6-well plates) on the day before transfection. Cells were transfected as previously described[42]. SIV vectors were produced by cotransfection with three plasmids: the SIV plasmid vector (pRMES8 or pGASE) $(1.7 \mu \mathrm{g}$ ), the helper plasmid, pSIV3 ${ }^{+}$, encoding Gag-Pol and regulatory proteins other than Env and Nef $(1.7 \mu \mathrm{g})$ and the envelope glycoprotein-encoding plasmid pGREV $(2.2 \mu \mathrm{g})$. The transfection medium was replaced after 16 hours of incubation. Virus-containing medium was collected 40 hours after transfection, clarified by centrifugation for 5 minutes at $800 \mathrm{~g}$, and passed through a filter with $0.45 \mu \mathrm{m}$ pores. For high-titer preparations, SIV vectors were concentrated by ultracentrifugation at $110,000 \mathrm{~g}$ for 2 hours. The viral pellet was resuspended by incubation for 2 hours at $4{ }^{\circ} \mathrm{C}$ in phosphate-buffered saline supplemented with $1 \%$ glycerol[34].

For determination of the infectious titer, sMAGI cells were seeded at a density of $4 \times 10^{5}$ cells $/ \mathrm{ml}$ in six-well plates one day before transduction in DMEM medium (Life Technologies Inc., Berlin, Germany) supplemented with $10 \%$ fetal bovine serum (FBS) (Gibco BRL, Grand Island, New York, USA), polybrene $(6 \mu \mathrm{g} / \mathrm{ml})$ (Sigma, Saint Louis, USA) and an antibiotic mixture $(5 \mathrm{mg} / \mathrm{ml}$ penicillin; $5 \mathrm{mg} / \mathrm{ml}$ streptomycin; $10 \mathrm{mg} / \mathrm{ml}$ neomycin; Gibco BRL, Grand Island, New York, USA). The cells were cultured for one day, and we then added serial dilutions of virus preparations and incubated the plates for a further four hours. Cells were then washed in DMEM (Life Technologies Inc., Berlin, Germany). Transduction rates was determined 48 hours after infection, as the percentage of GFP-positive sMAGI cells $\left(\% \mathrm{GFP}^{+} \mathrm{c}\right)$, by flow cytometry (FACScan, Becton Dickinson, San Jose, Mountain View,
California, USA) after transducing $4 \times 10^{5}$ cells with $1 \mathrm{ml}$ of diluted viral supernatant (dilution factor $=\mathrm{d}$ ). The infectious titer (IT), expressed as transducing units $/ \mathrm{ml}$, was calculated as: IT $=\% G F P^{+}$cells $\times 4 \times 10^{5} / 100 \times \mathrm{d}$.

\section{Transduction of immunoselected CD34+ cells}

Following immunoselection, CD34+ cells were cultured in a proliferation medium composed of Iscove's MDM supplemented with $1 \%$ bovine serum albumin (BSA), bovine pancreatic insulin $(10 \mu \mathrm{g} / \mathrm{ml})$, human transferrin $(200 \mu \mathrm{g} /$ $\mathrm{ml})$, 2-mercaptoethanol $\left(10^{-4} \mathrm{M}\right)$ and L-glutamine (2 $\mathrm{mM}$; Stemspan, Stem Cell Technologies, Meylan, France). The medium was supplemented with $50 \mathrm{ng} / \mathrm{ml}$ recombinant human (rh) SCF (Stem Cell Technologies, Meylan, France), 50 ng/ml rh Flt3-L (Stem Cell Technologies, Meylan, France), $10 \mathrm{ng} / \mathrm{ml}$ rh IL-3 (R\&D Systems, Minneapolis, USA), $10 \mathrm{ng} / \mathrm{ml}$ rh IL-6 (R\&D Systems, Minneapolis, USA) and $4 \mu \mathrm{g} / \mathrm{ml}$ polybrene (Sigma, Saint Louis, USA) in plates coated with retronectin (Cambrex Bio Science, Paris, France). The CD $34^{+}$cells were then transduced by 24 hours of coculture with the vector (multiplicity of infection $(\mathrm{MOI})=100)$.

\section{Myeloid differentiation of CD34+ cells}

Following the coculture of CD34+ cells with lentiviral vector, part of the cell culture was fixed in CellFix solution (Becton Dickinson, Erembodegem, Belgium) for evaluation of the rate of transduction of undifferentiated CD34+ cells. Part of the cell culture was cultured for 14 days in 35 $\mathrm{mm}$ Petri dishes containing semi-solid medium (Methocult GF H4434, Stem Cell Technologies, Meylan, France) composed of Iscove's MDM medium supplemented with $1 \%$ methylcellulose, $30 \%$ fetal bovine serum, $10^{-4} \mathrm{M} \mathrm{2-}$ mercaptoethanol, $2 \mathrm{mM}$ L-glutamine, $50 \mathrm{ng} / \mathrm{ml} \mathrm{rhSCF}, 10$ $\mathrm{ng} / \mathrm{ml} \mathrm{rhGM}-\mathrm{CSF}, 10 \mathrm{ng} / \mathrm{ml}$ rhIL-3 and $3 \mathrm{IU} / \mathrm{ml} \mathrm{rhEPO}$. Cells were cultured at a density of $10^{4}$ cells $/ \mathrm{ml}$ (in triplicate) at $37^{\circ} \mathrm{C}$, under an atmosphere containing $5 \% \mathrm{CO}_{2}$, to allow the myeloid differentiation of colony-forming cells (CFC).

The remaining cells were cocultured in 96-well plates for 35 days at $37^{\circ} \mathrm{C}$, under an atmosphere containing $5 \%$ $\mathrm{CO}_{2}$, on a layer of stromal cells of the murine fibroblastic cell line M2-10B4, in a medium composed of $\alpha$ MEM supplemented with $12.5 \%$ horse serum (HS), $12.5 \%$ FBS, 2 $\mathrm{mM}$ L-glutamine, $10^{-4} \mathrm{M}$ 2-mercaptoethanol, $0.16 \mathrm{M} \mathrm{I}$ inositol and $16 \mu \mathrm{M}$ folic acid (Myelocult H5100, Stem Cell Technologies, Meylan, France) and $10^{-6} \mathrm{M}$ hydrocortisone. Cells were cultured at a concentration of $10^{3}$ cells per well (24 wells per condition per monkey), to allow long-term culture-initiating cells (LTC-IC) to undergo myeloid differentiation to generate progenitor cells or CFC. The CFC were cultured for 14 days on semi-solid medium, as described above, to allow their myeloid differentiation into more mature cells. 


\section{AZT pretreatment of immunoselected $\mathrm{CD} 34^{+}$cells}

CD $34^{+}$cells were treated with AZT before transduction, to inhibit transduction due to reverse transcription of the lentiviral vector genome. Immunoselected $\mathrm{CD} 34^{+}$cells were cultured overnight in the proliferation medium described above, with AZT concentrations of $0,10^{-7}, 10^{-6}$ and $10^{-5}$ molar. The cells were washed twice and transduced with the lentiviral vector, according to the protocol described above. The real percentage of GFP-positive cells resulting from reverse transcription of the lentiviral vector was thus determined by subtracting the percentage of GFP-positive cells obtained after treatment with a saturating dose of AZT, from the percentage of GFP-positive cells obtained in the absence of AZT treatment.

\section{Fluorescence microscopy}

After transduction and myeloid differentiation in semisolid medium, the colonies formed by AZT-treated CFC were observed by fluorescence microscopy (Axiovert S100, Zeiss) using a magnification factor of 100. Fluorescence microscopy was used to detect GFP in each colony subtype, making it possible to determine the percentage of the colonies positive for GFP. We considered all colonies containing GFP-producing cells to be GFP-positive. Images were analyzed with Adobe Premiere and Adobe Photoshop software (Adobe Systems Inc., San Jose, CA, USA).

\section{Gamma irradiation}

Eight animals were sedated with ketamine (Imalgène; 10 $\mathrm{mg} / \mathrm{kg}$, i.m.), Rhône-Mérieux, France) and placed in a restraint chair. They received myeloablative conditioning, in the form of total body exposure to ${ }^{60} \mathrm{Co}$ gamma rays with an anterior unilateral direction. A total midline tissue dose of 6 Gy was delivered at a rate of $25.92 \mathrm{cGy} /$ minute. Dosimetry was performed, with $100 \mu \mathrm{L}$ ionization chambers placed in paraffin wax cylindrical phantoms of a similar size and orientation to the seated animal.

\section{Transplantation of modified $\mathrm{CD}^{+} 4^{+}$bone marrow cells}

After the coculture of $\mathrm{CD} 34^{+}$cells with the lentiviral vector, four animals underwent intramedullary infusion, of whole immunoselected $\mathrm{CD} 34^{+}$cells into both humeri (Table 1).

\section{Clinical support}

All animals received clinical support in the form of antibiotics and fresh irradiated whole blood, as required. An prophylactic antibiotic regimen was initiated when leukocyte count fell below $1,000 / \mu \mathrm{l}$ and continued daily until it exceeded 1,000/ $\mu \mathrm{l}$ for three consecutive days: $1 \mathrm{ml} / 10 \mathrm{~kg} /$ day Bi-Gental ${ }^{\oplus}$ (Schering-Plough Santé Animale) and 1 $\mathrm{ml} / 10 \mathrm{~kg}$ Terramycin ${ }^{\circledast}$ (Pfizer). Fresh, irradiated (25 Gy; ${ }^{137} \mathrm{Cs}$ gamma radiation) whole blood (approximately 50 $\mathrm{ml} /$ transfusion) from a random donor pool was administered if platelet count fell below 20,000/ $\mu \mathrm{l}$ and hemoglobin concentration was less than $6 \mathrm{~g} / \mathrm{dl}$.

\section{Flow cytometry analysis}

Peripheral blood and bone marrow mononuclear cells were incubated for $30 \mathrm{~min}$ at $4{ }^{\circ} \mathrm{C}$ with $10 \mu \mathrm{l}$ of selected monoclonal antibodies for single- or triple-color membrane staining. The following antibodies were used: APCconjugated anti-CD3 (SP34-2, Becton Dickinson), PEconjugated anti-CD14 (clone M5E2, BD Pharmingen), PE-conjugated anti-CD11b (BEAR-1, Beckman Coulter), PerCP-conjugated anti-CD20 (clone B9E9, Immunotech), PE-conjugated anti CD8 (clone RPA-T8, Becton Dickinson) and PerCP-conjugated antiCD4 (clone L200, BD Pharmingen). Cells were washed twice and fixed in CellFix solution (Becton Dickinson, Erembodegem, Belgium) for 3 days before analysis on a Becton Dickinson FACS apparatus with CellQuest Software (Becton Dickinson). eGFP fluorescence was detected in the isothiocyanate (FITC) channel. Negative controls from normal macaques were run with every experimental sample and were used to establish gates for eGFP quantification.

\section{Polymerase chain reaction (PCR) assays}

Cellular DNA was extracted from peripheral blood mononuclear cell (PBMC) samples, using the High Pure PCR Template Preparation Kit according to the manufacturer's instructions (Roche Mannheim, Germany). DNA was quantified by measuring optical density (Spectra Max 190; Molecular Devices, California, USA). The eGFP sequence was analyzed by quantitative real-time PCR on $250 \mathrm{ng}$ of DNA run on an iCycler real-time thermocycler (Bio-Rad, California, USA). Primers were as follows: forward primer, 5'ACGACGGCAACTACAAGACC3'; reverse primer, 5'GCCATGATATAGACGTTGTGG3'. Amplification was performed in a final volume of $50 \mu \mathrm{l}$, with $\mathrm{IQ}^{\mathrm{TM}}$

Table I: Reconstitution with transduced autologous CD34+ cells in irradiated cynomolgus macaques

\begin{tabular}{ccccc}
\hline Monkeys & CD34 ${ }^{+}$cells purity & CD34 cells collected & CD34+ cells transduced & CD34+ cells infused $/ \mathrm{kg}$ \\
\hline 6653 & $96.42 \%$ & $8.8 \times 10^{6}$ & $76.54 \%$ & $2.96 \times 10^{6}$ \\
6833 & $95.85 \%$ & $8.0 \times 10^{6}$ & $67.74 \%$ & $1.50 \times 10^{6}$ \\
6896 & $95.46 \%$ & $7.3 \times 10^{6}$ & $67.76 \%$ & $1.47 \times 10^{6}$ \\
7036 & $97.08 \%$ & $5.5 \times 10^{6}$ & $74.22 \%$ & $1.46 \times 10^{6}$ \\
\hline
\end{tabular}


SYBR $^{\oplus}$ Green Supermix (Bio-Rad, California, USA), in accordance with the manufacturer's instructions. Amplification was carried out over 40 cycles of denaturation at $95^{\circ} \mathrm{C}$, annealing at $59^{\circ} \mathrm{C}$ and elongation at $72^{\circ} \mathrm{C}$. Standard curves for the eGFP sequence were generated by serial 10 -fold dilutions of duplicate samples of the eGFP plasmid in DNA from untransduced PBMC, with 250 ng of total DNA in each sample. Samples from animals were run in duplicate, and the values reported correspond to the means for replicate wells.

\section{Statistical analysis}

Paired and unpaired comparisons were performed using non parametric Kruskal Wallis, Wilcoxon rank and Mann \& Whitney tests, respectively, both of which can be used for the analysis of small samples when normal distribution is uncertain or not confirmed. Tests were performed using StatView 5.01 sofware (Abacus Concepts, Berkeley, CA).

\section{Results \\ Efficient transduction of cynomolgus macaque CD34+ bone marrow cells}

We first assessed, in vitro, the efficiency with which a SIVmac251-derived vector transduced CD34+ hematopoietic cells from macaque bone marrow (BM). We harvested BM cells from the iliac crests of 12 different animals. $\mathrm{CD}_{3} 4^{+}$cell preparations with a purity of $97 \% \pm 1 \%$ were obtained by immunomagnetic purification. The CD34+ cells were then transduced by coculture for $24 \mathrm{~h}$ with the lentiviral vector $(\mathrm{MOI}=100)$ in medium supplemented with SCF, Flt3-L, IL-3 and IL-6. The vector used (pRMES8) was derived from SIVmac251 and contains the eGFP reporter gene under control of the phosphoglycerate kinase (pGK) promoter (Figure 1). Transduction efficiency (Figure 2A and 2B), as evaluated by flow cytometry analysis of eGFP expression at $24 \mathrm{~h}$, was $41 \% \pm 9 \%$ on average $(n=12)$. After 24 hours of culture with the lentiviral vector, some of the purified $\mathrm{CD} 34^{+}$cells were cultured for 14 days in semi-solid medium containing SCF, GM-CSF, IL-3 and EPO to allow the myeloid differentiation of colony-forming cells (CFC), whereas some cells were cocultured for 35 days on a layer of murine fibroblasts of the M2-10B4 cell line and were then cultured for 14 days on semi-solid medium containing SCF, GM-CSF, IL-3 and EPO, for the identification of long-term cultureinitiating cells (LTC-IC). Transduction had no effect on the clonogenic capacity of $\mathrm{CD} 34^{+}$cells: the mean number of colonies was $41 \pm 10$ for non transduced cells and $44 \pm$ 12 for pRMES8-transduced cells (12 animals tested, $\mathrm{P}=$ 0.60 (Mann \& Whitney test)). Similar results were obtained for LTC-IC, with $19 \pm 3$ colonies obtained for non transduced cells and $19 \pm 3$ for transduced cells $(\mathrm{n}=$ 12; $\mathrm{P}=0.79$ (Mann \& Whitney test)). Transduction rates did not differ significantly between CFC and LTC-IC (P =
0.4884 (Wilcoxon test), $\mathrm{n}=12$ ), with $18 \% \pm 7 \%$ and $19 \%$ $\pm 7 \%$ of colonies, respectively, eGFP-positive. However, in both cases, the percentage of eGFP-positive cells was significantly lower than that observed 24 hours after transduction $(\mathrm{P}<0.0001$ (Wilcoxon test)). This apparent discrepancy between analyses carried out at $24 \mathrm{~h}$ and analyses on CFC or LTC-IC may be due to the eGFP protein present in viral particles and incorporated into the cell cytoplasm during the coculture period. The proportion of cells producing eGFP shortly after transduction was reduced by $25 \% \pm 15 \%$ (Figure $2 \mathrm{C}$ ) if $10^{-6} \mathrm{M}$ AZT was added to cocultures of $\mathrm{CD} 34^{+} \mathrm{BM}$ cells and lentiviral vector $(\mathrm{MOI}=100)$. Untreated CFC cultures gave percentages of eGFP-producing cells similar to those observed before differentiation $(26 \% \pm 5 \%)$ (Figure 2D). No fluorescence was detected after myeloid differentiation of the AZTtreated CFC $(n=3)$, confirming that eGFP detection resulted from the production of this protein from integrated vector.

Mosaicism was observed in eGFP gene expression in several colonies (Figure 3). Indeed, eGFP was detected in $56 \% \pm 4 \%$ of colonies, whereas only $26 \% \pm 5 \%$ of individual cells were eGFP-positive. These results suggest that, on average, only $47 \%$ of cells from a single colony contained the SIV vector.

\section{Transplantation of autologous BM CD34+ cells transduced by SIV-based vector into cynomolgus macaques}

We explored the capacity of autologous CD34+BM cells transduced ex vivo with a lentiviral vector to engraft efficiently into macaques after total body irradiation (TBI) with a gamma source at the sublethal dose of $6 \mathrm{~Gy}$. Three groups of 4 animals were used: 1) In Group 1, macaque CD34+ BM cells $(96 \% \pm 1 \%$ pure on average $)$ were obtained from the two humeri before gamma irradiation (Table 1). These cells were cocultured, as described above, with pGASE, which is an improved version of pRMES8. Indeed, a mean transduction efficiency of $72 \% \pm 4 \%$ was obtained $(n=4)$ at 24 hours and $37 \% \pm 10 \%$ of CFC produced eGFP. Two days after gamma irradiation, $1.4 \times 10^{6}$ to $2.9 \times 10^{6} \mathrm{CD}^{2} 4^{+}$cells per $\mathrm{kg}$ were injected into both humeri of macaques (Table 1$) ; 2$ ) Group 2 included irradiated (6 Gy) macaques that did not undergo cell transplantation: 3) Group 3 included 4 non irradiated animals, which were used as controls, with a similar bleeding frequency.

\section{Reconstitution of hematopoietic cells in vivo}

Following total-body irradiation with $6 \mathrm{~Gy}$, transfusion and an antibiotic regimen were required to ensure that all the animals survived. However, one animal from group 1 (7036) died on day 40 due to profound pancytopenia (Figure 4). This macaque received the smallest number of autologous and transduced CD34+ BM cells. All other ani- 

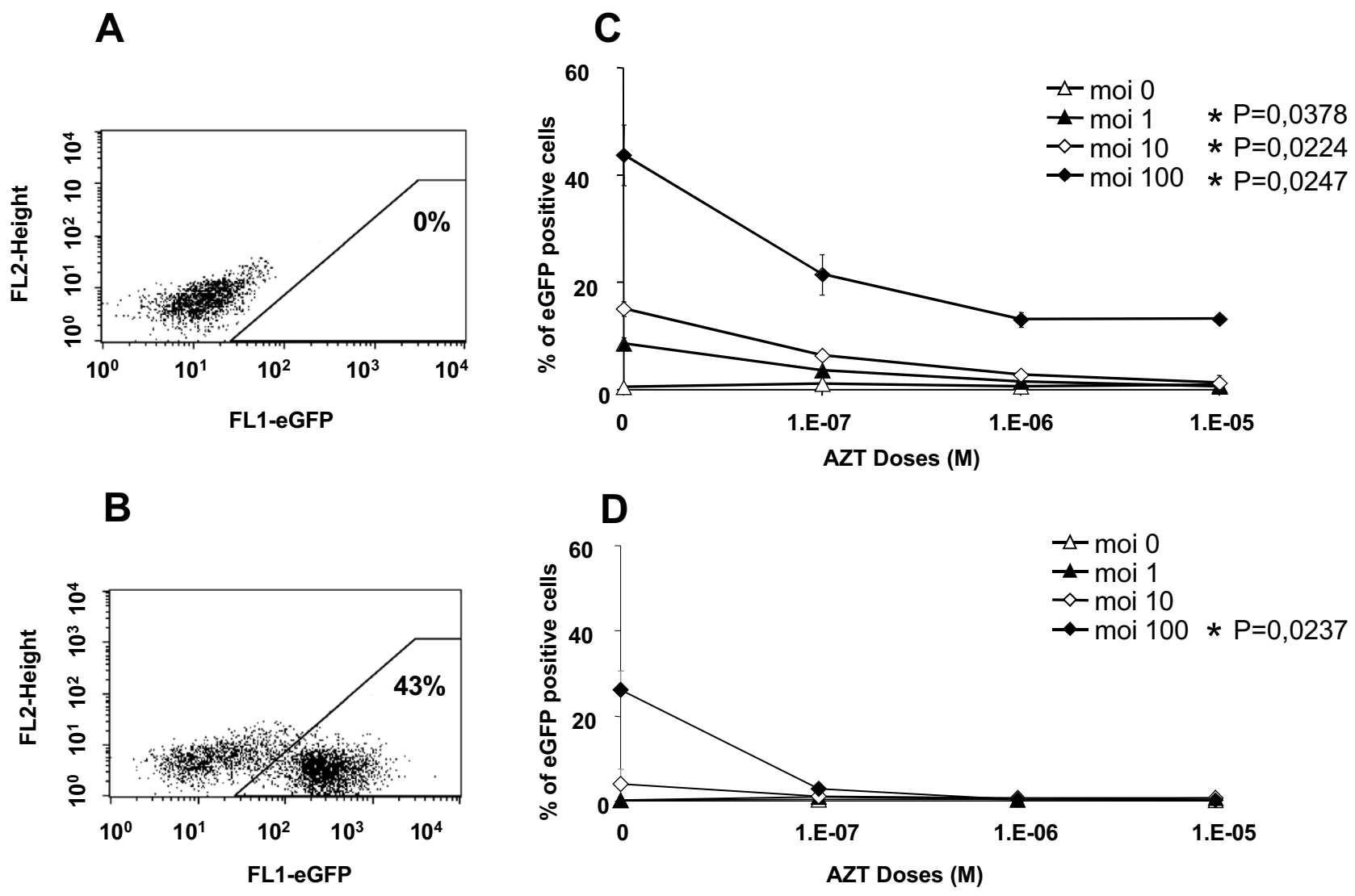

Figure 2

Efficiency of transduction of cynomologus macaque primitive hematopoietic cells with SIV-based lentiviral vectors. A: Non transduced cells were used as a control for each animal. B: Transduction of bone marrow progenitor cells with an SIV-based vector. $\mathrm{CD} 34^{+}$cells were cultured in the presence of cytokines (see materials and methods) and exposed to vector particles at an $\mathrm{MOI}$ of 100 for 24 hours before FACS analysis for eGFP production. C: CD34+ cells were cultured overnight in a proliferation medium supplemented with various concentrations of AZT (I00 nM, I mM, I0 mM). Cells were then washed twice and transduced with various multiplicities of infection (MOI) of the lentiviral vector $(0,1,10,100)$. After 24 hours of coculture with lentiviral vector, some of the $\mathrm{CD} 34^{+}$cells were used to evaluate the rate of transduction of undifferentiated $\mathrm{CD} 34^{+}$cells $(\mathrm{C})$; ${ }^{*}$ indicate statistically significant differences (Kruskal Wallis test) between cultures with and without AZT treatment for MOI = I $(p=0,0378), \mathrm{MOI}=10(p=0,0224)$ and $\mathrm{MOI}=100(p=0,0247)$. Some of the cells were cultured for 14 days, to allow the myeloid differentiation of CFC. Cells were then resuspended, washed and fixed for three days. They were analyzed by flow cytometry, to evaluate the percentage of eGFP-positive cells and determine the rate of transduction (D); * indicates a statistically significant difference $(p=0,0237($ Kruskal Wallis test)) between cultures with and without AZT treatment for MOI = I00. The results shown are the mean values for the three monkeys, each studied in triplicate.

mals from groups 1 and 2 were studied from days -1 to 471 after gamma irradiation. Controls were followed over the same period.

Radiation rapidly induced severe anemia in all animals (data not shown). A significant decrease in the number of polymorphonuclear cells in the periphery was observed, starting on day 1 after irradiation (Figure 4). No significant difference was observed between the animals of groups 1 and 2 in terms of the minimum number of cells $(821 \pm 226$ cells $/ \mu \mathrm{l}$ for group 1 and $658 \pm 107$ cells $/ \mu \mathrm{l}$ for group 2, P $=0.3768$ (Mann \& Whitney test)) or the time at which that minimum occurred $(6 \pm 5$ days for group 1 and 7 for group 2, P = 0.4795 (Mann \& Whitney test)). Lymphocyte counts also decreased in all macaques by day 1 after gamma irradiation (Figure 4), falling to a minimum of $220 \pm 107$ lymphocytes/ $\mu$ l on day $18 \pm 12$ in group 2 and of $347 \pm 62 / \mu \mathrm{l}$ on day $11 \pm 12$ in transplanted animals (group 1). Animals undergoing transplantation tended to display less severe lymphopenia, but no statistical difference was observed between the two groups of irradiated animals in terms of the day on which minimum 


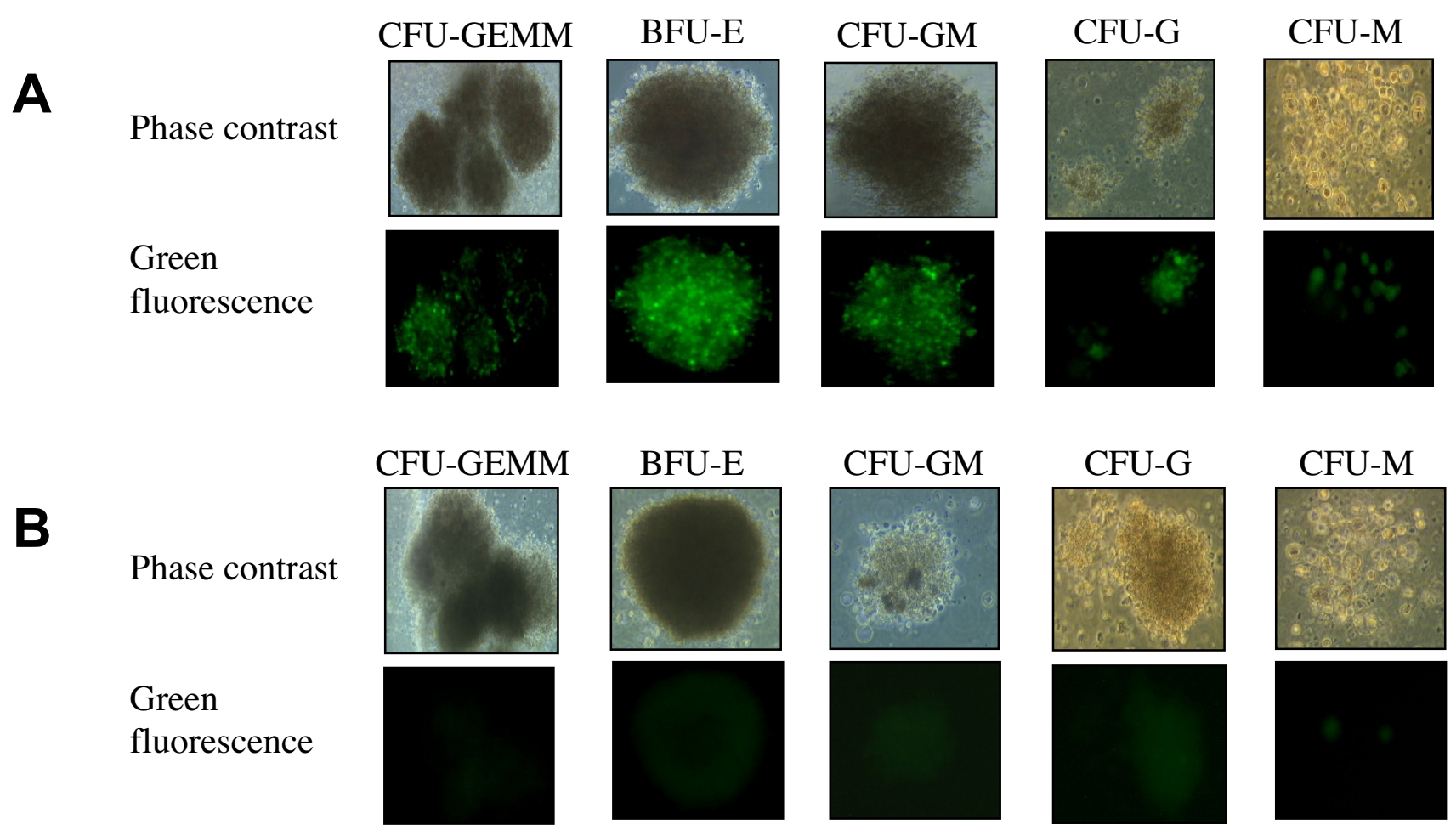

Figure 3

Fluorescence microscopy after myeloid differentiation of CFC $(\times 100)$. Freshly isolated CD34+ cells were transduced or not with the lentiviral vector ( 24 hours of culture with lentiviral vector at $\mathrm{MOI}=100)$. Cells were then cultured for 14 days in the presence of cytokines, to allow myeloid differentiation of transduced (A) and not transduced (B) CD34+ cells. Abbreviations: CFU-GEMM, Colony-Forming Unit-Granulocytes, Erythroid, Macrophage, Megakaryocyte; BFU-E, Burst-Forming Unit-Erythroid; CFU-GM, Colony-Forming Unit-Granulocytes, Macrophage; CFU-G, Colony-Forming Unit-Granulocytes; CFU-M, Colony-Forming Unit-Macrophage.

lymphocyte count was reached $(\mathrm{P}=0.1939$ (Mann \& Whitney test)) or the level of that minimum ( $\mathrm{P}=0.3805$ (Mann \& Whitney test)). A significant decrease in platelet counts, beginning by day 10 (Figure 4), was observed in all irradiated animals. Thrombocytopenia (platelet count $<20,000 / \mu \mathrm{l}$ ) was characterized in non transplanted animals by a minimum value of $3.75 \pm 2.49 \times 10^{3}$ platelets/ $\mu \mathrm{l}$ on day $18 \pm 3$. Thrombocytopenia tended to be less severe in transplanted animals, but this difference was not significant for the minimum number of platelets $(10.33 \pm$ $5.25 \times 10^{3}$ platelets $/ \mu \mathrm{l} ; \mathrm{P}=0.1124$ (Mann \& Whitney test)) or for the day on which that minimum occurred $(14.33 \pm 0.94 ; \mathrm{P}=0.3123$ (Mann \& Whitney test)). This thrombocytopenia required one transfusion in all animals (other than animal 7036, which needed two transfusions) of both groups. However, platelet reconstitution seemed to be correlated with the dose of CD $34^{+}$cells infused, the speed of reconstitution increasing with the number of CD $34^{+}$cells injected (macaque 6653).

\section{Reconstitution of bone marrow clonogenic activity}

We determined the effects of CD34+ bone marrow cell transplantation following gamma irradiation on the ex vivo proliferation and differentiation of hematopoietic progenitors. Before gamma irradiation, a mean of $40 \pm 9$ and $38 \pm 6$ colonies was observed for groups 1 and 2, respectively (Figure 5). Colony number decreased significantly $(\mathrm{P}<0.0001$ (Wilcoxon test)) by day 7 in all animals. In both groups, clonogenic activity was detected by day 43 after gamma irradiation with reconstitution significantly better in the animals undergoing transplantation than in those that did not undergo transplantation ( $\mathrm{P}=$ 0.0009 (Mann \& Whitney test)).

\section{Presence of eGFP-positive cells in bone marrow and peripheral blood}

Cells with integrated SIV-vector DNA were detected by PCR (Table 2) as early as day 3 after transplantation, in at least two animals (6653 and 6833). These two animals had received the largest numbers of transduced CD $34^{+}$ bone marrow cells. Monkey 7036, which died within 40 

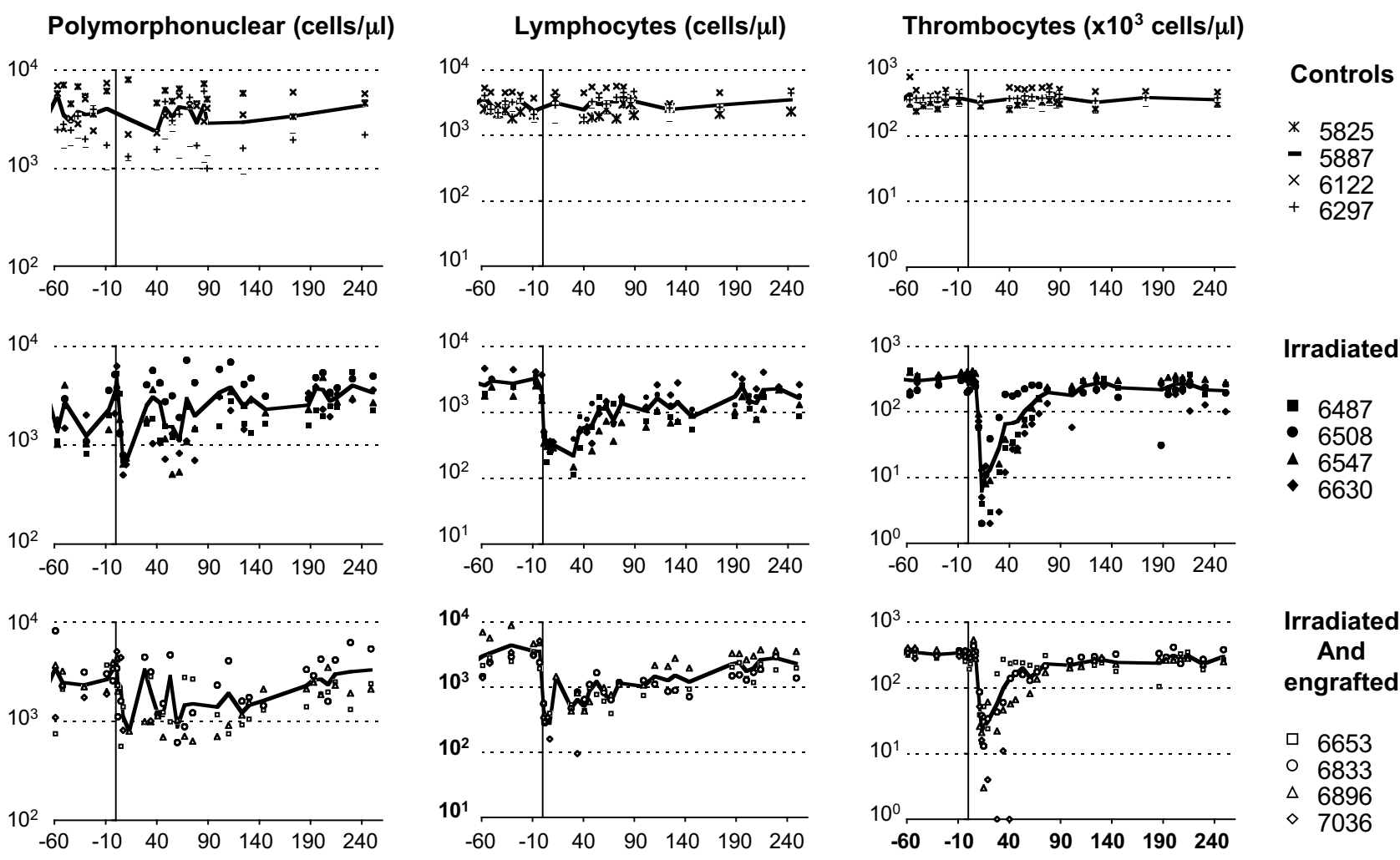

Irradiated
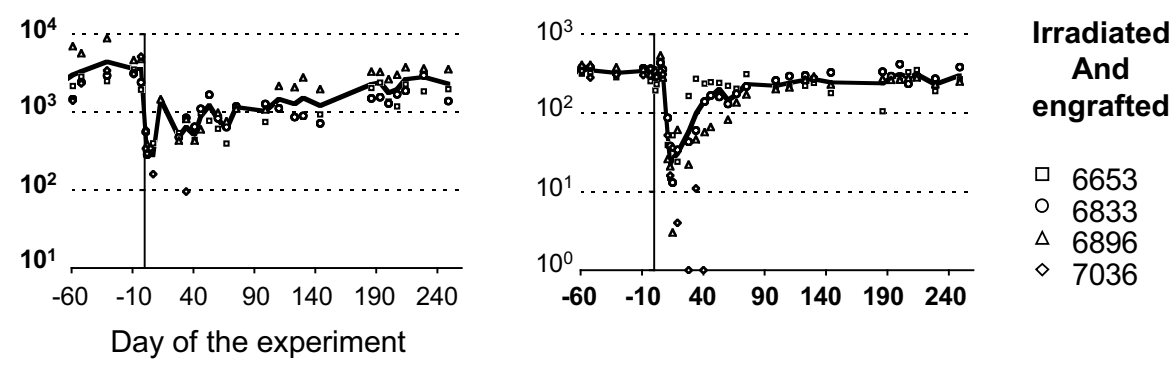

\section{Figure 4}

Effect of irradiation and transplantation on polymorphonuclear cell, lymphocyte and thrombocyte counts. All animals were followed during the weeks preceding the study, and for more than 240 days after the irradiation. We carried out hematological analysis including blood cell counts with an automated hemocytometer (Coulter Corporation, Miami, USA).

days of gamma irradiation had very few transduced cells in the bone marrow and SIV-DNA was not detected in peripheral blood cells. In the three remaining animals, vector DNA was detected in peripheral blood cells (up to
500 copies per million cells) and in the bone marrow (up to 6250 copies per million cells) more than one year after transplantation (day 471).

Table 2: Number of DNA copies per million mononuclear cells in peripheral blood (PB) and bone marrow (BM)

\begin{tabular}{|c|c|c|c|c|c|c|c|c|}
\hline \multirow[b]{3}{*}{ Days post transplantation } & \multicolumn{8}{|c|}{ Monkey } \\
\hline & \multicolumn{2}{|c|}{6653} & \multicolumn{2}{|c|}{6833} & \multicolumn{2}{|c|}{6896} & \multicolumn{2}{|c|}{7036} \\
\hline & PB & $\mathrm{BM}$ & $\mathrm{PB}$ & $\mathrm{BM}$ & PB & $\mathrm{BM}$ & $\mathrm{PB}$ & $\mathrm{BM}$ \\
\hline-3 & 0 & 0 & 0 & 0 & 0 & 0 & 0 & 0 \\
\hline 3 & 500 & ND & 250 & ND & 0 & ND & 0 & 15 \\
\hline 5 & 250 & 500 & ND & 250 & ND & ND & 0 & 0 \\
\hline 108 & 250 & ND & 250 & ND & 1250 & ND & $*$ & $*$ \\
\hline 121 & 750 & ND & 250 & ND & 250 & ND & $*$ & $*$ \\
\hline 128 & 250 & ND & 250 & ND & 250 & ND & $*$ & $*$ \\
\hline 142 & 250 & ND & 250 & ND & 1750 & 3250 & $*$ & $*$ \\
\hline 47I & ND & 250 & 250 & 250 & 500 & 6250 & $*$ & $*$ \\
\hline
\end{tabular}

ND: not determined

*: 7036 died on day 40 


\section{$\square$ Not transplanted - Transplanted}

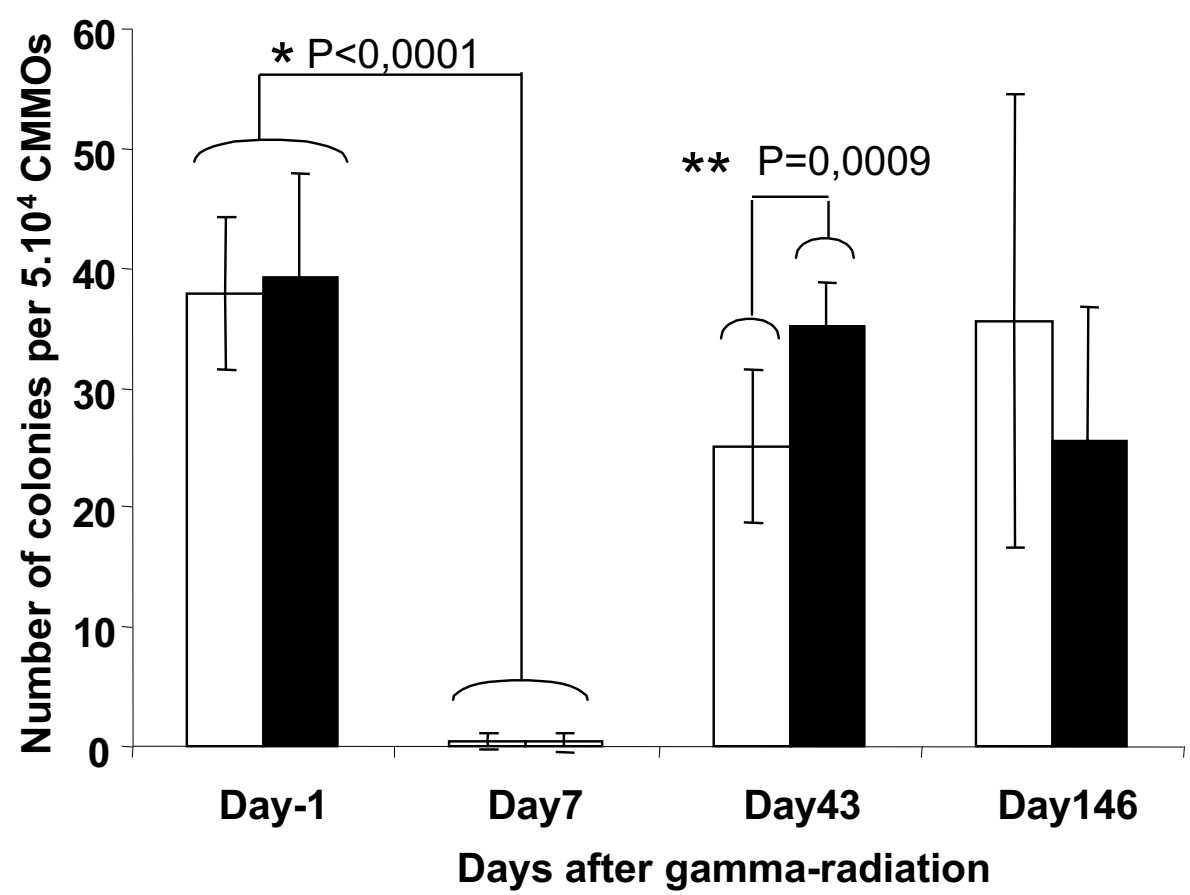

\section{Figure 5}

Recovery of bone marrow clonogenic activity. Bone marrow-derived colony-forming units following sublethal irradiation of cynomolgus monkeys transplanted (black bars) or not transplanted with CD $34^{+}$cells (open bars). Mean \pm SD of CFC number (triplicate). The results of statistical test are indicates; $*$ indicates a statistically significant difference $(p<0,000$ I (Wilcoxon test)) between day 0 and day 7 for the both group; ** indicates a statistically significant difference $(p=0,0009$ (Mann \& Whitney test)) at day 43 between animals undergoing transplantation and those that did not undergo transplantation.

Flow cytometry analysis demonstrated the presence of eGFP-producing cells among peripheral blood mononuclear cells in myeloid and lymphoid lineges of monkey 6896 (Figure 6). Peripheral blood cells were sorted on the basis of eGFP production, with the aim of characterizing the phenotype of populations of cells expressing the transgene in more detail. We found that $61 \%$ of eGFP-positive cells were CD11b-positive, $5 \%$ of these cells appeared to be CD $14+$ monocytes, $14 \%$ were CD20+ B cells and 10\% were CD $3+$ T cells, $23 \%$ of which expressed CD 8 and $77 \%$ expressed CD4 (data not shown).

\section{Discussion}

The aim of this work was to study reconstitution of the myeloid and lymphoid compartments after the autologous transplantation of genetically modified CD34+ bone marrow cells into cynomolgus macaques previously subjected to gamma irradiation.
We first assessed, in vitro, the efficiency with which a SIVmac251-derived vector transduced macaque CD $34^{+}$ hematopoietic bone marrow cells. These vectors are similar to those derived from HIV. However, SIV-derived vectors clearly outperform HIV-derived vectors in simian cells. In fact, HIV-1 fails to replicate in simian cells because of an early postentry block $[43,44]$, and Kootstra et., al showed that the viral determinant involved in postentry restriction of $\mathrm{HIV}-1$ replication in simian cells is located at or near the cyclophilin A (CyPA) binding region of the capside protein [45]. The hydrophobic pocket of cyclophilin A (CypA) makes direct contact with an exposed, proline-rich loop on HIV-1 capsid (CA) and renders reverse transcription complexes resistant to an antiviral activity in human cells. A CypA fusion with TRIM5 (a member of the tripartite motif family) that is unique to New World owl monkeys also targets HIV-1 CA, but this interaction potently inhibits infection. A similar block to HIV-1 infection in Old World monkeys is attributable to the $\alpha$ isoform of the TRIM5 orthologue in these 

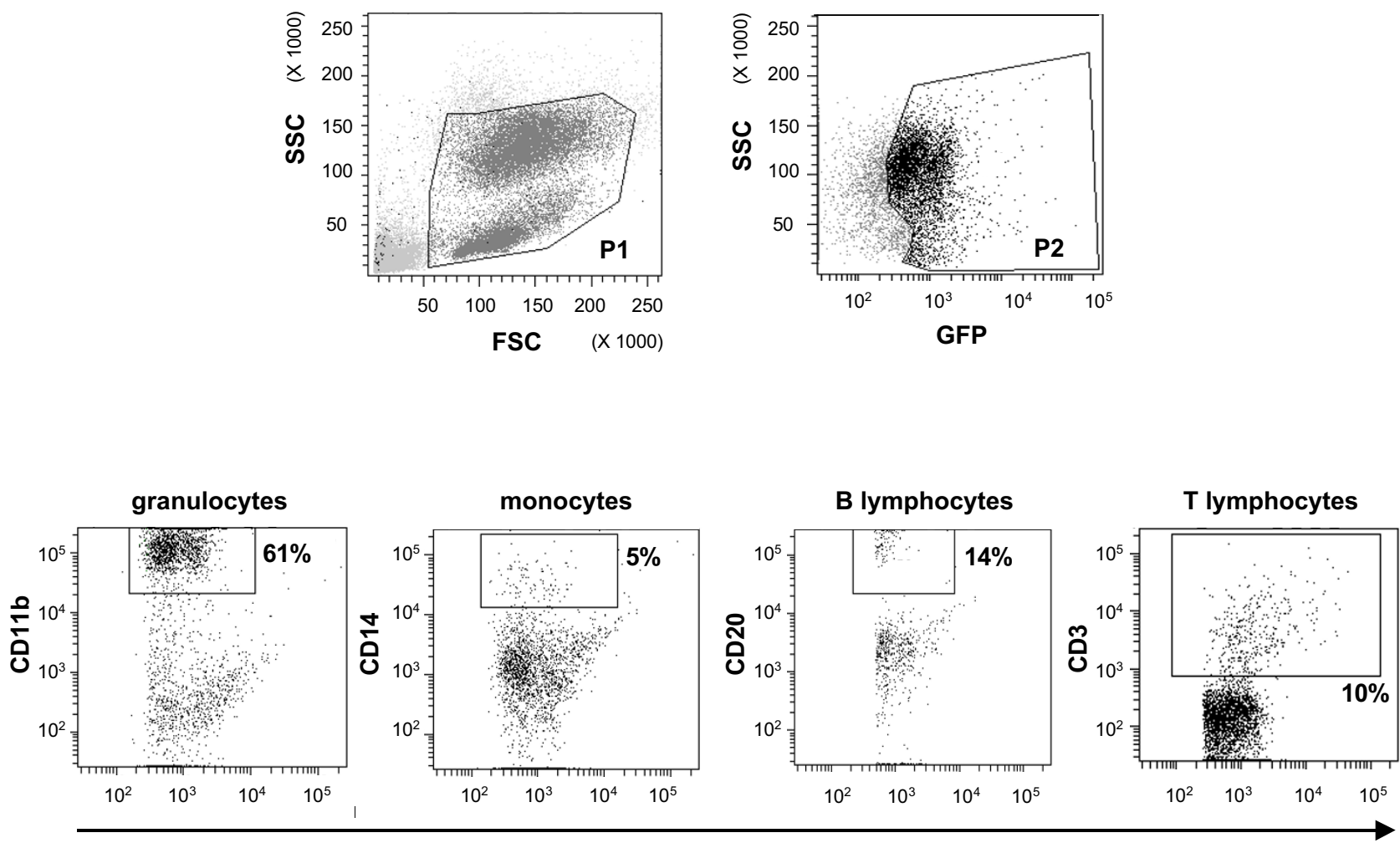

GFP

Figure 6

Flow cytometry analysis of hematopoiesis reconstitution. Animal transplanted with autologous CD34+ bone marrow cells transduced with an SIV-based vector. eGFP-positive cells present in PI and P2 were analyzed by immuno-staining to identify the subpopulations of eGFP-positive cells in peripheral blood. CD20-PerCP-Cy5, CDI4-PE, CDI Ib-APC and CD3-APC staining were used to identify the B-lymphocyte, monocyte, granulocyte and T-lymphocyte subpopulations.

species and using RNA interference techniques, Berthoux et., al demonstrated that CypA inhibits HIV-1 replication in these cells because it is required for CA recognition by TRIM5 $\alpha$ [46]. SIV vectors can also efficiently transduce human cells $[33,47]$, and may therefore prove a useful alternative to HIV-1-based vectors, at least in the early phase of preclinical testing of lentivirus vectors. We found that the proportion of eGFP-positive cells obtained before myeloid differentiation (mean value of $30 \%$ ) was similar to that obtained with CD $34^{+}$cells from human donors transduced with lentiviral [48-51], retroviral [52-54], AAV[55], or adenovirus/AAV-derived [56] vectors. However, it is possible to increase the transduction rate, such that $90 \%$ transduced human $\mathrm{CD} 34^{+}$cells are obtained from cord blood, $80 \%$ from bone marrow and $75 \%$ from G-CSF mobilized peripheral blood [57]. We analyzed transduction in two types of assay, based on committed (CFC) and primitive (LTC-IC) hematopoietic progenitors, as analyses of the transduction of committed progenitors only bear little relation to the transduction efficiency for stem cells and less differentiated cells in the long term.
After myeloid differentiation, eGFP+ ${ }^{+}$cells were detected, in similar proportions, in CFC on day 15 and LTC-IC on day 50 after transduction, indicating that the vector was able to transduce progenitor cells and most immature hematopoietic cells with a similar efficiency. Similar results have been reported for stimulated human CFC and LTC-IC, which were found to be transduced with similar efficiency by a lentiviral vector based on HIV-1[58]. In this previous study, significant resistance to lentiviral transduction was reported in unstimulated primitive human cells. These results may explain why, in our study, the use of cytokines during transduction made possible the genetic modification of LTC-IC, which are quiescent. Cytokine treatment may have led to these cells entering the cell cycle, facilitating transduction. This result confirms the greater efficiency of lentiviral vectors than of retroviral vectors for the transduction of CD34+ cells. Nevertheless, in our study, only half as many eGFP-positive cells were obtained after differentiation as were obtained from undifferentiated CD $34^{+}$cells. Similar observations have been made with MLV-transduced progenitor cells from human 
donors[59]. We demonstrate here that these differences may be accounted for by the pseudotransduction detected at $24 \mathrm{~h}$ of incubation with the vector, confirming the results reported with $\mathrm{CD} 34^{+}$cells in studies using VSVgpseudotyped MLV-derived[60] or lentivirus-derived vectors[51]. It has been suggested that pseudotransduction may result from VSVg-pseudotyping due to membrane fusion efficiency being higher than the rate of integration of the transgene[61]. Nevertheless, most lentiviral vectors have been generated with VSV-G, as this glycoprotein makes it easy to recover and concentrate the pseudotyped vectors [62].

We also showed that eGFP was produced in all colony subtypes. Clusters of eGFP production were observed on fluorescence microscopy, indicating that not all the cells of a given positive colony - theoretically derived from a single cell - produced eGFP. This result is consistent with those of Mikkola et al. concerning murine HSC transduction by a VSVg-pseudotyped lentiviral vector, in which a mismatch was reported between the transduction rate of cells (almost 25\%) and the transduction rate of myeloid colonies (almost 60\%). These authors highlighted the occurrence of mosaicism in GFP gene expression in colonies obtained following the myeloid differentiation of CD34+ cells[63], possibly due to a delay in the integration of the transgene during differentiation, resulting in the formation of clusters of GFP-positive cells within a single myeloid colony.

In our in vivo study, autologous HSC were injected into the bone marrow, whereas intravenous injection is currently the most frequently used transplantation method. We aimed to increase seeding efficiency and homing, as only a limited number of stem cells were theoretically available. However, $2.5 \times 10^{6}$ to $5.0 \times 10^{6} \mathrm{CD} 34^{+}$cells is generally sufficient to ensure engraftment, and we found that less than $2.0 \times 10^{6}$ cells were sufficient for long-term reconstitution in macaques. As predicted[64,65], totalbody gamma irradiation leads to a drastic decrease in the number of hematopoietic progenitors, preventing the development of mature cells [66]. Despite the occurrence of severe pancytopenia, a positive correlation has been found between the number of $\mathrm{CD} 34^{+}$cells infused and time required for immune reconstitution $[42,67,68]$. However, hematopoietic recovery may take longer if fewer than $2.0 \times 10^{6} \mathrm{CD} 34^{+}$cells $/ \mathrm{kg}$ are infused. This notion is consistent with our observation that $\mathrm{CD} 34^{+}$cell transplantation decreases both the severity and duration of irradiation-induced cytopenia. Clonogenic activity also reappeared more strongly in transplanted animals. We also showed that the animals recovered $\mathrm{B}$ cells, $\mathrm{T}$ cells, monocytes and granulocytes. Nevertheless, the functional activity of these cells requires confirmation, particularly for lymphocytes. However, although we observed long- term reconstitution with lentiviral vector-transduced cells of different lineages, its proportion remained below $1 \%$. Hanawa et al., provided the first evidence that SIV-based vectors can successfully transduce rhesus macaque repopulating hematopoietic stem cells, with an average of $16 \%$ of peripheral blood leukocytes containing the SIV vector genome. However, this study was carried out with HSC from mobilized peripheral blood cells, making it possible to obtain larger numbers of HSC than can be harvested from bone marrow. Nevertheless theoretically, these cells contained more progenitors that were already committed and fewer pluripotent stem cells capable of long-term reconstitution than medullary HSC[69]. The small numbers of eGFP-producing cells observed in our study may be due to an anti-eGFP immune response. Some reports have suggested that such reactions do not generally occur after irradiation[70], but two reports described the induction of cytotoxic T-lymphocyte responses to enhanced green (GFP) or yellow (YFP) fluorescent proteins after myeloablative conditioning. One of these reports concerned baboons that had received primitive hematopoietic cells transduced with HIV-1-based lentiviral vectors[71] and the other concerned rhesus macaques that had received $\mathrm{CD} 34^{+}$stem cells transduced with a retroviral vector[72].

Lentiviruses, like retroviruses, can be used to integrate transgenes into the host genome. Two severe adverse events occurred in two patients in the SCID-X1 gene therapy trial 30 to 34 months after injection of the autologous $\mathrm{CD} 34^{+}$cells corrected using a retroviral vector. In these patients, an uncontrolled clonal $\mathrm{T}$ lymphoproliferative syndrome, similar to acute lymphoblastic leukemia, was observed $[73,74]$. This study highlights the risk of insertional mutagenesis restricted to retroviral and lentiviral gene transfer. In the future, additional safety measures could be considered, such as the use of self-inactivating LTRs (as in our study) to reduce enhancer activity, the addition of insulators to reduce the risk further, and the insertion of a second transgene encoding a "suicide" product, such as herpes thymidine kinase, making it possible to kill the transduced cells with ganciclovir. Unlike studies in mice, in which the follow-up period is necessarily limited, studies in large animals, with a longer life span, are compatible with more extensive follow-up. The development of linear amplification-mediated PCR (LAM-PCR), a sensitive and robust approach to molecular clonal analysis, has made it possible to identify and analyze the contribution of individual transduced clones to hematopoiesis. Clonal analysis may provide information about the dominance of transduced clones, potentially predicting possible progression or the propensity to develop clonal hematopoiesis and leukemia. Moreover, replication-competent retrovirus (RCRs), recombinant retrovirus and interaction with endogenous retroviruses 
should also be investigated, when evaluating the biosafety of retrovirus and lentivirus.

\section{Conclusion}

The results reported here provide the first evidence that gene transfer into medullary hematopoietic stem cells and long-term expression of the transgene are possible, using an SIV-based lentiviral vector in non human primates, which provide the best clinical models for in vivo evaluation of the feasibility and safety of gene therapy strategies.

\section{Competing interests}

The authors never received reimbursements, fees, funding, or salary from an organization that may in any way gain or lose financially from the publication of this paper. The authors never have any stocks or shares in an organization that may in any way gain or lose financially from the publication of this paper. The authors have no competing interests to declare in relation to this paper.

\section{Authors' contributions}

$\mathrm{SD}$ was the main contributor to this paper. This work is part of her PhD project. She carried out transduction of CD $34^{+}$cells, transplantation of animals, PCR for identification of cells expressing the transgene in vivo, flow cytometry analysis, WG Have improved assays for transduction of macaque bone marrow CD34+ cells with SIV derived vector, DN constructed and produced the SIV derived vector, SP technical assistance to cell sorting, MLD technical assistance to transplantation, BD technical assistance to cell culture, flow cytometry and irradiadion of NHP, GA technical assistance to molecular biology, TA technical assistance to flow cytometry and cell sorting, JLL irradiation of animals and dosimetry, FLC supervises vector design and production, RLG supervisor of SD.

\section{Acknowledgements}

We would like to thank M. Ripaux, A. Fort, S. Jacquin, D. Mérigard, P. Pochard, D. Renault, J. C. Wilks and R. Rioux for excellent technical assistance. This work was supported by the Agence Nationale de Recherches sur le SIDA (ANRS, Paris, France), the Centre de Recherches du Service de Santé des Armées Emile Pardé (CRSSA, La Tronche, France), and the Commissariat à l'Energie Atomique (CEA, Fontenay aux Roses, France).

\section{References}

I. Miller DG, Adam MA, Miller AD: Gene transfer by retrovirus vectors occurs only in cells that are actively replicating at the time of infection. Mol Cell Biol 1990, I0:4239-4242.

2. Jones RJ, Wagner JE, Celano P, Zicha MS, Sharkis SJ: Separation of pluripotent haematopoietic stem cells from spleen colonyforming cells. Nature 1990, 347:188-189.

3. Gothot A, Loo JC van der, Clapp DW, Srour EF: Cell cycle-related changes in repopulating capacity of human mobilized peripheral blood CD34(+) cells in non-obese diabetic/severe combined immune-deficient mice. Blood 1998, 92:264I-2649.

4. Hao QL, Thiemann FT, Petersen D, Smogorzewska EM, Crooks GM: Extended long-term culture reveals a highly quiescent and primitive human hematopoietic progenitor population. Blood 1996, 88:3306-3313.
5. Ploemacher RE, Sluijs JP van der, Voerman JS, Brons NH: An in vitro limiting-dilution assay of long-term repopulating hematopoietic stem cells in the mouse. Blood 1989, 74:2755-2763.

6. Ploemacher RE, Sluijs JP van der, van Beurden CA, Baert MR, Chan PL: Use of limiting-dilution type long-term marrow cultures in frequency analysis of marrow-repopulating and spleen colony-forming hematopoietic stem cells in the mouse. Blood 1991, 78:2527-2533.

7. Traycoff CM, Kosak ST, Grigsby S, Srour EF: Evaluation of ex vivo expansion potential of cord blood and bone marrow hematopoietic progenitor cells using cell tracking and limiting dilution analysis. Blood 1995, 85:2059-2068.

8. Bodine DM, Crosier PS, Clark SC: Effects of hematopoietic growth factors on the survival of primitive stem cells in liquid suspension culture. Blood I991, 78:9|4-920.

9. Larochelle A, Vormoor J, Hanenberg H, Wang JC, Bhatia M, Lapidot T, Moritz T, Murdoch B, Xiao XL, Kato I, et al.: Identification of primitive human hematopoietic cells capable of repopulating NOD/SCID mouse bone marrow: implications for gene therapy. Nat Med 1996, 2:1329-1337.

10. Peters SO, Kittler EL, Ramshaw HS, Quesenberry PJ: Ex vivo expansion of murine marrow cells with interleukin-3 (IL-3), IL-6, IL-I I, and stem cell factor leads to impaired engraftment in irradiated hosts. Blood 1996, 87:30-37.

II. Tisdale JF, Hanazono Y, Sellers SE, Agricola BA, Metzger ME, Donahue RE, Dunbar CE: Ex vivo expansion of genetically marked rhesus peripheral blood progenitor cells results in diminished long-term repopulating ability. Blood |998, 92: I |3|-| | 4 |.

12. Lewis PF, Emerman M: Passage through mitosis is required for oncoretroviruses but not for the human immunodeficiency virus. J Virol 1994, 68:510-516.

13. Naldini $L$ : Lentiviruses as gene transfer agents for delivery to non-dividing cells. Curr Opin Biotechnol 1998, 9:457-463.

14. Fouchier RA, Malim MH: Nuclear import of human immunodeficiency virus type-I preintegration complexes. Adv Virus Res 1999, 52:275-299.

15. Naldini L, Blomer U, Gallay P, Ory D, Mulligan R, Gage FH, Verma IM, Trono $D$ : In vivo gene delivery and stable transduction of nondividing cells by a lentiviral vector. Science 1996, 272:263-267.

16. Richardson JH, Kaye JF, Child LA, Lever AM: Helper virus-free transfer of human immunodeficiency virus type I vectors. J Gen Virol 1995, 76(Pt 3):691-696.

17. Arya SK, Zamani M, Kundra P: Human immunodeficiency virus type 2 lentivirus vectors for gene transfer: expression and potential for helper virus-free packaging. Hum Gene Ther 1998, 9:137|-1380

18. Poeschla EM, Wong-Staal F, Looney DJ: Efficient transduction of nondividing human cells by feline immunodeficiency virus lentiviral vectors. Nat Med 1998, 4:354-357.

19. Mitrophanous K, Yoon S, Rohll J, Patil D, Wilkes F, Kim V, Kingsman S, Kingsman A, Mazarakis N: Stable gene transfer to the nervous system using a non-primate lentiviral vector. Gene Ther 1999, 6:1808-1818.

20. Hu J, Dunbar CE: Update on hematopoietic stem cell gene transfer using non-human primate models. Curr Opin Mol Ther 2002, 4:482-490.

21. Donahue RE, Dunbar CE: Update on the use of nonhuman primate models for preclinical testing of gene therapy approaches targeting hematopoietic cells. Hum Gene Ther 200I, I 2:607-6I7.

22. Villinger F, Brar SS, Mayne A, Chikkala N, Ansari AA: Comparative sequence analysis of cytokine genes from human and nonhuman primates. J Immunol 1995, I 55:3946-3954.

23. Farese AM, MacVittie TJ, Roskos L, Stead RB: Hematopoietic recovery following autologous bone marrow transplantation in a nonhuman primate: effect of variation in treatment schedule with PEG-rHuMGDF. Stem Cells 2003, $21: 79-89$.

24. Dunbar CE, Takatoku M, Donahue RE: The impact of ex vivo cytokine stimulation on engraftment of primitive hematopoietic cells in a non-human primate model. Ann N Y Acad Sci 200I, 938:236-244. discussion 244-235.

25. Wagemaker G, Neelis KJ, Hartong SCC, Wognum AW, Thomas GR, Fielder PJ, Eaton DL: The efficacy of recombinant TPO in murine And nonhuman primate models for myelosuppression and stem cell transplantation. Stem Cells 1998, I6(Suppl 2): $|27-| 4 \mid$ 
26. Shi PA, Hematti P, von Kalle C, Dunbar CE: Genetic marking as an approach to studying in vivo hematopoiesis: progress in the non-human primate model. Oncogene 2002, 21 :3274-3283.

27. Burkhard MJ, Dean GA: Transmission and immunopathogenesis of FIV in cats as a model for HIV. Curr HIV Res 2003, I:I5-29.

28. Willett BJ, Flynn JN, Hosie MJ: FIV infection of the domestic cat: an animal model for AIDS. Immunol Today 1997, I 8: I82-I89.

29. Talbott RL, Sparger EE, Lovelace KM, Fitch WM, Pedersen NC, Luciw $\mathrm{PA}$, Elder $\mathrm{J}$ : Nucleotide sequence and genomic organization of feline immunodeficiency virus. Proc Natl Acad Sci USA 1989, 86:5743-5747.

30. Olmsted RA, Barnes AK, Yamamoto JK, Hirsch VM, Purcell RH, Johnson PR: Molecular cloning of feline immunodeficiency virus. Proc Natl Acad Sci USA 1989, 86:2448-2452.

31. Schnell T, Foley P, Wirth M, Munch J, Uberla K: Development of a self-inactivating, minimal lentivirus vector based on simian immunodeficiency virus. Hum Gene Ther 2000, I I:439-447.

32. Wagner R, Graf M, Bieler K, Wolf H, Grunwald T, Foley P, Uberla K: Rev-independent expression of synthetic gag-pol genes of human immunodeficiency virus type I and simian immunodeficiency virus: implications for the safety of lentiviral vectors. Hum Gene Ther 2000, I I:2403-24I3.

33. Negre D, Mangeot PE, Duisit G, Blanchard S, Vidalain PO, Leissner $P$ Winter AJ, Rabourdin-Combe C, Mehtali M, Moullier P, et al:: Characterization of novel safe lentiviral vectors derived from simian immunodeficiency virus (SIVmac25I) that efficiently transduce mature human dendritic cells. Gene Ther 2000, 7:1613-1623.

34. Mangeot PE, Negre D, Dubois B, Winter AJ, Leissner P, Mehtali M, Kaiserlian D, Cosset FL, Darlix JL: Development of minimal lentivirus vectors derived from simian immunodeficiency virus (SIVmac25 I) and their use for gene transfer into human dendritic cells. J Virol 2000, 74:8307-83।5.

35. Kiem HP, Andrews RG, Morris J, Peterson L, Heyward S, Allen JM, Rasko JE, Potter J, Miller AD: Improved gene transfer into baboon marrow repopulating cells using recombinant human fibronectin fragment $\mathrm{CH}-296$ in combination with interleukin-6, stem cell factor, FLT-3 ligand, and megakaryocyte growth and development factor. Blood 1998 92:1878-1886.

36. Wu T, Kim HJ, Sellers SE, Meade KE, Agricola BA, Metzger ME, Kato I, Donahue RE, Dunbar CE, Tisdale JF: Prolonged high-level detection of retrovirally marked hematopoietic cells in nonhuman primates after transduction of CD34+ progenitors using clinically feasible methods. Mol Ther 2000, I:285-293.

37. Kim HJ, Tisdale JF, Wu T, Takatoku M, Sellers SE, Zickler P, Metzger ME, Agricola BA, Malley JD, Kato I, et al.: Many multipotential gene-marked progenitor or stem cell clones contribute to hematopoiesis in nonhuman primates. Blood 2000, 96:1-8.

38. Rosenzweig M, MacVittie TJ, Harper D, Hempel D, Glickman RL, Johnson RP, Farese AM, Whiting-Theobald N, Linton GF, Yamasaki G, et al:: Efficient and durable gene marking of hematopoietic progenitor cells in nonhuman primates after nonablative conditioning. Blood 1999, 94:227I-2286.

39. Kelly PF, Donahue RE, Vandergriff JA, Takatoku M, Bonifacino AC Agricola BA, Metzger ME, Dunbar CE, Nienhuis AW, Vanin EF: Prolonged multilineage clonal hematopoiesis in a rhesus recipient of CD34 positive cells marked with a RDII4 pseudotyped oncoretroviral vector. Blood Cells Mol Dis 2003 , 30:132-143.

40. Hu J, Kelly P, Bonifacino A, Agricola B, Donahue R, Vanin E, Dunbar CE: Direct comparison of RDII4-pseudotyped versus amphotropic-pseudotyped retroviral vectors for transduction of rhesus macaque long-term repopulating cells. Mol Ther 2003, 8:6 I I-6I7.

41. Mangeot PE, Duperrier K, Negre D, Boson B, Rigal D, Cosset FL, Darlix JL: High levels of transduction of human dendritic cells with optimized SIV vectors. Mol Ther 2002, 5:283-290.

42. Chen $\mathrm{C}$, Okayama $\mathrm{H}$ : High-efficiency transformation of mammalian cells by plasmid DNA. Mol Cell Biol 1987, 7:2745-2752.

43. Munk C, Brandt SM, Lucero G, Landau NR: A dominant block to HIV-I replication at reverse transcription in simian cells. Proc Natl Acad Sci USA 2002, 99: I 3843- I 3848

44. Besnier C, Takeuchi $Y$, Towers G: Restriction of lentivirus in monkeys. Proc Natl Acad Sci USA 2002, 99: I I 920-I I 925.
45. Kootstra NA, Munk C, Tonnu N, Landau NR, Verma IM: Abrogation of postentry restriction of HIV-I-based lentiviral vector transduction in simian cells. Proc Natl Acad Sci USA 2003, I00:1298-1303.

46. Berthoux L, Sebastian S, Sokolskaja E, Luban J: Cyclophilin A is required for TRIM5\{alpha\}-mediated resistance to HIV-I in Old World monkey cells. Proc Natl Acad Sci USA 2005, 102: | 4849-| 4853 .

47. Sandrin V, Boson B, Salmon P, Gay W, Negre D, Le Grand R, Trono $D$, Cosset FL: Lentiviral vectors pseudotyped with a modified RDII4 envelope glycoprotein show increased stability in sera and augmented transduction of primary lymphocytes and CD34+ cells derived from human and nonhuman primates. Blood 2002, 100:823-832.

48. Sutton RE, Wu HT, Rigg R, Bohnlein E, Brown PO: Human immunodeficiency virus type I vectors efficiently transduce human hematopoietic stem cells. J Virol 1998, 72:578I-5788.

49. Evans JT, Kelly PF, O'Neill E, Garcia JV: Human cord blood CD34+CD38- cell transduction via lentivirus-based gene transfer vectors. Hum Gene Ther 1999, I 0:1479-| 489.

50. Piconi S, Trabattoni D, Fusi ML, Milazzo F, Dix LP, Rizzardini G Colombo F, Bray D, Clerici M: Effect of two different combinations of antiretrovirals (AZT+ddl and AZT+3TC) on cytokine production and apoptosis in asymptomatic HIV infection. Antiviral Res 2000, 46: I7I-I79.

5I. Case SS, Price MA, Jordan CT, Yu XJ, Wang L, Bauer G, Haas DL, Xu $D$, Stripecke R, Naldini L, et al.: Stable transduction of quiescent CD34(+)CD38(-) human hematopoietic cells by HIV-I-based lentiviral vectors. Proc Natl Acad Sci USA 1999, 96:2988-2993.

52. Poznansky MC, La Vecchio J, Silva-Arietta S, Porter-Brooks J, Brody K, Olszak IT, Adams GB, Ramstedt U, Marasco WA, Scadden DT: Inhibition of human immunodeficiency virus replication and growth advantage of CD4+ $T$ cells and monocytes derived from CD34+ cells transduced with an intracellular antibody directed against human immunodeficiency virus type I Tat. Hum Gene Ther 1999, 10:2505-2514.

53. Rosenzweig M, Marks DF, Hempel D, Lisziewicz J, Johnson RP: Transduction of CD34+ hematopoietic progenitor cells with an antitat gene protects $\mathrm{T}$-cell and macrophage progeny from AIDS virus infection. J Virol 1997, 71:2740-2746.

54. Davis BR, Saitta FP, Bauer G, Bunnell BA, Morgan RA, Schwartz DH: Targeted transduction of CD34+ cells by transdominant negative Rev-expressing retrovirus yields partial anti-HIV protection of progeny macrophages. Hum Gene Ther 1998, 9:1197-1207.

55. Chatterjee S, Li W, Wong CA, Fisher-Adams G, Lu D, Guha M, Macer JA, Forman SJ, Wong KK Jr: Transduction of primitive human marrow and cord blood-derived hematopoietic progenitor cells with adeno-associated virus vectors. Blood 1999 , 93: $1882-1894$.

56. Shayakhmetov DM, Carlson CA, Stecher H, Li Q, Stamatoyannopou los G, Lieber A: A high-capacity, capsid-modified hybrid adenovirus/adeno-associated virus vector for stable transduction of human hematopoietic cells. J Virol 2002, 76: I I35-I I 43.

57. Amsellem S, Ravet E, Fichelson S, Pflumio F, Dubart-Kupperschmitt A: Maximal lentivirus-mediated gene transfer and sustained transgene expression in human hematopoietic primitive cells and their progeny. Mol Ther 2002, 6:673-677.

58. Zielske SP, Gerson SL: Cytokines, including stem cell factor alone, enhance lentiviral transduction in nondividing human LTCIC and NOD/SCID repopulating cells. Mol Ther 2003 7:325-333.

59. Yam PY, Yee JK, Ito JI, Sniecinski I, Doroshow JH, Forman SJ, Zaia JA: Comparison of amphotropic and pseudotyped VSV-G retroviral transduction in human CD34+ peripheral blood progenitor cells from adult donors with HIV-I infection or cancer. Exp Hematol 1998, 26:962-968.

60. Liu ML, Winther BL, Kay MA: Pseudotransduction of hepatocytes by using concentrated pseudotyped vesicular stomatitis virus G glycoprotein (VSV-G)-Moloney murine leukemia virus-derived retrovirus vectors: comparison of VSV-G and amphotropic vectors for hepatic gene transfer. J Virol 1996 , 70:2497-2502.

61. Gallardo HF, Tan C, Ory D, Sadelain M: Recombinant retroviruses pseudotyped with the vesicular stomatitis virus $\mathbf{G}$ glycoprotein mediate both stable gene transfer and 
pseudotransduction in human peripheral blood lymphocytes. Blood 1997, 90:952-957.

62. Burns JC, Friedmann T, Driever W, Burrascano M, Yee JK: Vesicular stomatitis virus $\mathbf{G}$ glycoprotein pseudotyped retroviral vectors: concentration to very high titer and efficient gene transfer into mammalian and nonmammalian cells. Proc Natl Acad Sci USA 1993, 90:8033-8037.

63. Mikkola H, Woods NB, Sjogren M, Helgadottir H, Hamaguchi I, Jacobsen $\mathrm{SE}$, Trono D, Karlsson S: Lentivirus gene transfer in murine hematopoietic progenitor cells is compromised by a delay in proviral integration and results in transduction mosaicism and heterogeneous gene expression in progeny cells. J Virol 2000, 74: $11911-11918$.

64. Bolus NE: Basic review of radiation biology and terminology. J Nucl Med Technol 200I, 29:67-73. test 76-67.

65. MacVittie TJ, Farese AM, Herodin F, Grab LB, Baum CM, McKearn JP: Combination therapy for radiation-induced bone marrow aplasia in nonhuman primates using synthokine SC-55494 and recombinant human granulocyte colony-stimulating factor. Blood 1996, 87:4129-4|35.

66. Dainiak N: Hematologic consequences of exposure to ionizing radiation. Exp Hematol 2002, 30:5। 3-528.

67. Nieboer P, de Vries EG, Vellenga E, Graaf WT van der, Mulder NH, Sluiter WJ, de Wolf JT: Factors influencing haematological recovery following high-dose chemotherapy and peripheral stem-cell transplantation for haematological malignancies; I-year analysis. Eur J Cancer 2004, 40: I 199-1207.

68. Jillella AP, Ustun C: What is the optimum number of CD34+ peripheral blood stem cells for an autologous transplant? Stem Cells Dev 2004, 13:598-606.

69. Hanawa H, Hematti P, Keyvanfar K, Metzger ME, Krouse A, Donahue RE, Kepes S, Gray J, Dunbar CE, Persons DA, Nienhuis AW: Efficient gene transfer into rhesus repopulating hematopoietic stem cells using a simian immunodeficiency virus-based lentiviral vector system. Blood 2004, 103:4062-4069.

70. Persons DA, Allay JA, Riberdy JM, Wersto RP, Donahue RE, Sorrentino BP, Nienhuis AW: Use of the green fluorescent protein as a marker to identify and track genetically modified hematopoietic cells. Nat Med 1998, 4:120I-1205.

7I. Morris JC, Conerly M, Thomasson B, Storek J, Riddell SR, Kiem HP: Induction of cytotoxic T-lymphocyte responses to enhanced green and yellow fluorescent proteins after myeloablative conditioning. Blood 2004, 103:492-499.

72. Rosenzweig M, Connole M, Glickman R, Yue SP, Noren B, DeMaria $M$, Johnson RP: Induction of cytotoxic T lymphocyte and antibody responses to enhanced green fluorescent protein following transplantation of transduced CD34(+) hematopoietic cells. Blood 200I, 97:195I-1959.

73. Hacein-Bey-Abina S, von Kalle C, Schmidt M, Le Deist F, Wulffraat N, Mclntyre E, Radford I, Villeval JL, Fraser CC, Cavazzana-Calvo M, Fischer A: A serious adverse event after successful gene therapy for $\mathbf{X}$-linked severe combined immunodeficiency. $N$ Engl I Med 2003, 348:255-256

74. Hacein-Bey-Abina S, Von Kalle C, Schmidt M, McCormack MP, Wulffraat N, Leboulch P, Lim A, Osborne CS, Pawliuk R, Morillon E, et al.: LMO2-associated clonal $\mathrm{T}$ cell proliferation in two patients after gene therapy for SCID-XI. Science 2003, 302:4I5-4I9.
Publish with Bio Med Central and every scientist can read your work free of charge

"BioMed Central will be the most significant development for disseminating the results of biomedical research in our lifetime. "

Sir Paul Nurse, Cancer Research UK

Your research papers will be:

- available free of charge to the entire biomedical community

- peer reviewed and published immediately upon acceptance

- cited in PubMed and archived on PubMed Central

- yours - you keep the copyright
BioMedcentral 